
ЗАСОБАМИІНТЕРАКТИВНОГО НАВЧАННЯНА УРОКАХ АНГЛЙСЬКОӤ МОВИ

of students. These three aspects build students' intrinsic motivation, or in other words their inner desire to acquire second language.

\section{REFERENCES}

1. Deci, E.L. \& Rayan, R.M. (1985). Intrinsic motivation and self-determination in human behavior.

2. Dörnyei Z., Motivational Strategies in the Language Classroom, 2001 Cambridge Cambridge University Press.

3. Gardner, R.C. \& Lambert, W.E (1972). Attitudes and Motivation in second language learning. Rowley, MA: Newbury House.

4. Masgoret, A. M. \& Gardner, R.C. Attitudes,
Motivation and Second language Learning. A MetaAnalysis of Studies. Conducted by Gardner and Associates. Article in Language Learning 53(S1), pp.167-210. May 2003.

5. Matt Delong and Dale Winter, Learning to Teaching and Teaching to Learn Mathematics: Resources for Professional Development, Mathematical Association of America, 2002.

6. ELT Journal, Volume 61, Issue 4, 1 October 2007, pp. 369-371. Available at: https://doi.org/ 10.1093/elt/ccm056

7. Available at: www.teachenglish.org.uk

8. Available at: https://cft.vanderbilt.edu/guidessub-pages/motivating_students.

Стаття надійшла до редакції 18.03.2019

УДК 378.091.33:811.111]:004.031.42

DOI:

Карина Авраменко, асистент кафедри англійської філології та методики викладання англійської мови

Мелітопольського державного педагогічного університету імені Богдана Хмельницького

\title{
УДОСКОНАЛЕННЯ МЕТОДИЧНОЇ ПІДГОТОВКИ МАЙБУТНІХ ПЕДАГОГІЧНИХ ПРАЦІВНИКІВ ЗАСОБАМИ ІНТЕРАКТИВНОГО НАВЧАННЯ НА УРОКАХ АНГЛІЙСЬКОї МОВИ
}

У статті розглядається методична підготовка як складова загальної професійної підготовки майбутніх педагогічних прачівників на уроках англійської мови, а також вказані можсливі методи ї̈ вдосконалення. Зокрема, визначено роль засобів інтерактивного навчання у иьому проиесі. Виокремлено найбільш ефективні з точки зору розвитку професійної компетентності методи інтерактивного навчання (робота в парах/трійках; "Карусель"; дискусії, ділові ігри, аналіз ситуаиій; метод акваріуму; "Мозаїка"; рольові методи; “Мікрофон”; “Мозковий штурм" та “брейн-ринг”), експериментально доведено їхню ефективність у підвищенні методичної майстерності майбутніх вчителів англійської мови.

Ключові слова: методична підготовка; професійна компетентність; інтерактивне навчання; педагогічний працівник.

Jim. 10.

Karyna Avramenko, Assistant of the English Philology and Methods of Teaching English Department Melitopol Bohdan Khmelnytskiy State Pedagogical University

\section{IMPROVEMENT OF METHODICAL PREPARATION OF FUTURE TEACHERS BY MEANS OF INTERACTIVE LEARNING IN THE ENGLISH LANGUAGE}

The article deals with methodological training as a component of the General professional training of future teachers in English lessons, as well as the possible methods of its improvement. In particular, the role of interactive learning tools in this process is defined. The most effective from the point of view of development of professional competence methods of interactive training (work in pairs / threes; "Carousel"; discussions, business games, analysis of situations; aquarium method; "Mosaic"; role-playing methods; "Microphone"; "Brainstorming" and brain-ring), experimentally proved their effectiveness in improving the methodological skills of future teachers of English.

Now the system of educational process is at the stage of active development and changes. In connection with these processes, the training of future teachers acquires almost a leading role, which is confirmed by the fact that society has significant expectations from the educational reform and from new personnel in the education system in particular. It is obvious that the basis for the formation of their own individual style of students of pedagogical universities lay during training. During this period, the most effective and acceptable to use in their experience means and methods of training are also determined. 


\section{УДОСКОНАЛЕННЯ МЕТОДИЧНОЇПІДГОТОВКИ МАЙБУТНІХПЕДАГОГІЧНИХ ПРАЦІВНИКІВ ЗАСОБАМИІНТЕРАКТИВНОГО НАВЧАННЯНА УРОКАХ АНГЛЙСЬКОӤ МОВИ}

The relevance of the study is explained by the importance of improving the process of methodological training of future teachers in connection with educational reforms. We emphasize that special training about teaching methods and interactive means of teaching at lessons of a foreign language dedicated to a lot of work. However, the issue of improving the methodological training of future teachers by means of interactive learning in English lessons works are almost not presented.

The prospect of further research is seen in the possibility of a detailed consideration of individual methods in the context of methodological training of future teachers, as well as in the conduct of experimental tests of the effectiveness of these methods among students of pedagogical higher educational institutions.

Keywords: methodical training of future teachers; professional competence; interactive learning; an educational worker.

П остановка проблеми. Наразі система освітнього процесу знаходиться на етапі активного розвитку та змін. У зв'язку з цими процесами підготовка майбутніх педагогічних працівників набуває чи не провідної ролі, що підтверджується тим, що у суспільстві $є$ значні очікування від освітньої реформи та від нових кадрів у системі освіти зокрема [9]. Очевидно, що основи формування власного індивідуального стилю у студентів педагогічних вишів закладаються вже під час навчання. У цей період так само визначаються найбільш ефективні та прийнятні до застосування у власному досвіді засоби та методи навчання.

Саме тому важливо, щоб майбутні педагогічні працівники здобували у процесі навчання професійну компетентність, зокрема, і методичну. В умовах пришвидшених і масштабніших процесів євроінтеграції в Україні необхідно звертати особливу увагу на вивчення іноземної мови (англійської зокрема) як на складову загальної компетентності фахівця. Удосконалення розмовних навичок значно розширює можливості педагога до саморозвитку: до прикладу, з'являється більше шансів брати участь у програмах обміну викладацьким досвідом (у тому числі, і міжнародних); здатність опановувати найсучасніші розробки мовою оригіналу; можливість стати частиною світового наукового товариства. Таким чином, опанування мов міжкультурної комунікації посідає чільне місце у методичній підготовці майбутнього педагогічного працівника. Завданнями викладачів педагогічних вишів у цьому контексті $є$ спрямування студентів на особистісно орієнтовану технологію навчання, визначення пріоритетності індивідуального підходу у веденні власної професійної діяльності. Через це необхідно навчати студентів, не відкидаючи традиційні форми роботи, але і застосовуючи нові та більш сучасні - інтерактивні засоби зокрема.

Актуальність дослідження пояснюється важливістю удосконалення процесу методичної підготовки майбутніх педагогічних працівників у зв'язку з освітніми реформами. Підкреслимо, що окремо методичній підготовці та інтерактивним засобам навчання на уроках іноземної мови присвячено багато робіт. Утім, питанню вдосконалення методичної підготовки майбугніх педагогічних працівників засобами інтерактивного навчання на уроках англійської мови робіт майже не представлено. Також варто додати, що у зв'язку з тим, що теоретичні сентенції не встигають за практичними інноваціями у сфері педагогіки вищої школи, ця тема потребуе детального дослідження та практичного застосування.

Аналіз останніх публікацій. Ми фокусували увагу на ознайомленні з науковими розвідками у сфері педагогіки (вищої школи зокрема), враховуючи тематичну специфіку нашого дослідження. Ці питання висвітлено у дослідженнях О.Б. Бігич, О.О. Дідух, М.В. Дука, І.В. Зайцевої, М.С. Глазунова, І.А. Княжевої, Т.І. Коробейнікової, М.М. Марій, О.Б. Хомищак, А.Ю. Циркаль, О.В. Ярошенко. Ці науковці активно розглядають інтерактивні засоби навчання різного спрямування у контексті методичної підготовки майбугніх фахівців, а також розвиток мовної компетенції студентів вищих навчальних закладів.

Метою дослідження $\epsilon$ дослідження способів удосконалення методичної підготовки майбутніх педагогічних працівників засобами інтерактивного навчання на уроках англійської мови, а також виявлення уцьому ключі найефективніших засобів інтерактивного навчання.

Виклад основного матеріалу. Методична підготовка - складне поняття, уніфікованого визначення якого не представлено у роботах теоретиків педагогіки, особливо з урахуванням інновацій у цій сфері. Саме тому для повнішого розуміння терміну пропонуємо навести декілька цитат із наукових розвідок, в яких пропонуються власні визначення цього процесу, а також його компоненти і функції у педагогіці.

До прикладу, Т. Бодрова зазначає, що методична підготовка - це "у широкому розумінні $<$...> багатогранний феномен, система організації та управління навчанням, форма здобування фахової освіти, у вузькому - це педагогічний 


\section{УДОСКОНАЛЕННЯ МЕТОДИЧНОЇПЦДГОТОВКИ МАЙБУТНІХПЕДАГОГІЧНИХ ПРАЦІВНИКІВ ЗАСОБАМИІНТЕРАКТИВНОГО НАВЧАННЯНА УРОКАХАНГЛЙСЬКОӤ МОВИ}

процес, результатом якого на етапі завершення навчання $є$ оволодіння студентами відповідними компетентностями” [3]. І. Княжева зазначає, що методична підготовка “. . . .зближує загальнопедагогічний i спеціальний напрями вишівської професійнопедагогічної підготовки майбутніх викладачів педагогічних дисциплін, що дозволяє їм поєднувати теоретичні знання з уміннями їх застосовувати для вирішення відповідних практичних завдань, забезпечує розуміння теорії і досвіду навчання та володіння необхідними для його відтворення педагогічними методиками i технологіями, теорію та практику в навчальновиховному процесі вищої педагогічної школи" [5]. У науковій статті В. Безлюдної вказано, що методична підготовка складається зі “знання теорії та володіння навичками та вміннями працювати 3 мовним матеріалом при його введенні, закріпленні і активізація, формування методичного мислення" [2].

Вдосконалення методичної підготовки розглядала викладач Т. Зубенко, вказуючи, що для цього існує "необхідність створення оптимальної системи <..>, яка б поєднувала наступні компоненти: використання різних форм організації навчальної діяльності у вищій педагогічній школі: традиційні (лекції, лабораторні й практичні заняття, СРС та НДРС) з нетрадиційними (методичний театр, участь уроботі методичних об'єднань шкіл, самоосвіта) тощо; включення активних методів навчання (дидактичні ігри та педагогічні імітації, методичні ринги та аукціони методичних знань, трансформування передового досвіду та власний методичний пошук тощо); перегляд програмового матеріалу з позицій переносу акценту на формування у майбутніх учителів методичних умінь та створення відповідного навчальнометодичного забезпечення" [4]. Погодимося 3 авторкою, адже така система давала б змогу студентам краще пізнати себе та власні ресурси; відзначити для своєї майбутньої педагогічної практики найкращі методи роботи; опиралася б на індивідуальний підхід, який наразі є трендом в освіті.

У контексті особистісного підходу варто зосередити увагу на засобах інтерактивного навчання, адже воно характеризується як “навчання у співпраці, коли і слухачі, і педагог $\epsilon$ суб’єктами навчання; <..> здатність до взаємодії, навчання у режимі бесіди, діалогу, дії; $<\ldots>$ метод, в якому той, хто навчається, $є$ учасником" [8]. Проаналізувавши вибрану літературу, а також спираючись на власний викладацький досвід, ми створили список найбільш ефективних засобів інтерактивного навчання, які використовуються на уроках англійської мови. Ефективність розглядається 3 точки зору розвитку професійної компетентності та покращення методичної підготовки майбутніх педагогів. Нумерація списку не відповідає ранжуванню засобів. Отже:

У першу чергу, для вдосконалення методичної підготовки педагогів важливим $€$ всебічне знання сучасних програм і підручників, а також додаткових засобів освіти; розуміння складнощів, які можуть виникнути під час опанування предмета. Інформацію про те, які методи краще спрацьовують у цьому аспекті, знаходимо у роботі I. Козаченко: “Якщо заняття спрямоване на закріплення нового лексичного, граматичного матеріалу, можна використовувати метод “мозкового штурму”, роботу в парах, в малих групах, метод незакінчених речень, метод “навчаючи-учусь” [7]. Детальніше розглянемо кілька з них у наступних пунктах.

Робота в парах/трійках. Цей метод М. Соснова описує так: “Студенти працюють в парах, виконуючи завдання. Парна робота вимагає обміну думками і дозволяє швидко виконати вправи, які в звичайних умовах є часомісткими або неможливими < .. >. Робота в трійка - по суті, це ускладнена робота в парах. Найкраще в трійках проводити обговорення, обмін думками, підведення підсумків чи навпаки, виділення несхожих думок” [10]. У контексті вдосконалення методичної підготовки цей метод дозволяє вплинути на кілька аспектів. У першу чергу, вміння чітко формулювати власні погляди на певні ситуації у рамках предмета або ж резюмувати думки колег дозволить майбутнім педагогам бути готовими до методичної роботи (зокрема, участі у загальних зборах, конференціях, семінарах, обмінах досвідом тощо). По-друге, його застосування вплине на вміння майбутніх педагогічних працівників організовувати учнів у процесі навчання.

“Карусель”. Л. Бабенко надає детальний опис цього методу: “. ...об’єднуються в дві групи. Кожна група обирає лідера, в обов'язки якого входять керівництво процесом обговорення і узагальнення колективної думки. Протягом певного часу кожна група опрацьовує запропоноване питання. Сформульовані відповіді записують. Педагоги розміщуються утворюючи зовнішне та внутрішне коло один навпроти одного) по типу каруселі. < .. > Кожна група ознайомившись 3 відповідями та думками колег, вносить свої доповнення. Групи обмінюють формулярами доти, доки кожна група не одержить свій власний варіант розробки обраного питання. Кожна група готує стисле 


\section{УДОСКОНАЛЕННЯ МЕТОДИЧНОӤПІДГОТОВКИ МАЙБУТНІХПЕДАГОГІЧНИХ ПРАЦІВНИКІВ ЗАСОБАМИІНТЕРАКТИВНОГО НАВЧАННЯ НА УРОКАХ АНГЛІЙСЬКОӤ МОВИ}

повідомлення" [1]. Вважаємо такий метод ефективним із точки зору підготовки майбугнього педагога до роботи у вчительському колективі, розвитку навиків ділового спілкування та вміння знаходити спільні методичні рішення. На нашу думку, його застосування може вплинути і на здатність майбутніх педагогів керувати позакласною і позашкільною роботою з відповідного предмета.

Окрім цього, для розвитку вказаних у двох попередніх пунктах умінь і навичок, так само доцільними будуть використання методів групових бесід, дискусій, рольових і ділових ігор, аналіз ситуацій і метод акваріуму [7].

Для опанування методикою викладання (знаннями дидактики, психології та методів навчання) найкращим є використання методів мозаїки, адже, як зазначається у роботі "Використання інтерактивних технологій в навчально-виховному процесі": Такий вид діяльності на уроці дає можливість вам працювати разом, щоб вивчити значну кількість інформації за короткий проміжок часу, а також заохочує вас допомагати один одному вчитися навчаючи" [6]. Саме цей метод дає змогу впоратись iз великим масивом теоретичної інформації, тому вважаємо, що “Мозаїку” варто застосовувати у контексті опанування основ дидактики, психології та педагогіки.

Для поглиблення теоретичних знань і вміння застосовувати теоретичні знання у практичному спілкуванні з учнями (зокрема, вільного володіння мовою та демонстрування вмінь працювати 3 наочним матеріалом на тему предмета) ефективними є рольові методи (розігрування ситуацій в ролях). Про це згадується у роботі I. Козаченко: "На етапі вдосконалення мовленнєвих умінь, ефективними є такі методи, як дискусії в стилі ток-шоу, прес-конференції, проектні методи" [7].

Метод роботи “Мікрофон” дозволяє тренувати вміння організувати учнів на уроці та зацікавити в участі всіх учнів у навчанні, адже він “...надає можливість кожному сказати щось швидко, по черзі, відповідаючи на запитання або висловлюючи свою думку чи позицію; <..> коли хтось висловлюється, інші не мають права перебивати, щось говорити, викрикувати з місця” [6].

“Мозковий штурм“, на нашу думку, може бути корисним майбутнім педагогічним працівникам у контексті підготовки до роботи над позанавчальними заходами, адже, як зазначає Л. Бабенко його використовують “...під час колективного планування певної діяльності чи заходу, для накопичення ідей, пошуку рішень, виявлення знань або асоціацій учасників із заданого питання" [1].
Брейн-ринг може застосовуватися у контексті загальної теоретичної підготовки майбутніх педагогів, а також для закріплення навиків спілкування у педагогічному колективі, адже це “пізнавальна гра, яка сприяє закріпленню теоретичних та уточненню знань вихователів, передбачає колективні завдання, розвиток умінь педагогів знаходити правильні рішення педагогічних проблем", правила організації якої “1) обов'язкова участь всіх педагогів; 2 ) регламентованість у часі; 3) прийняття будь яких думок та відповідей; 4) формування узагальнень та висновків" [1].

Окрім цього, важливою складовою методичної підготовки сучасного педагогічного працівника $\epsilon$ вміння працювати 3 інноваційними технічними засобами навчання (проектори, аудіовізуальне обладнання, інтерактивні дошки, планшети, мікрофони, системи відеозв' язку та синхронного перекладу тощо). Окрему увагу варто приділяти використанню інтерактивної дошки на уроках англійської умови, адже це - багатофункціональний інструмент, який дозволяє підсилювати ефект від використання інтерактивних технологій. Як свідчить практика власного педагогічного досвіду, за іiї допомогою можна включити у навчання всіх студентів, адже вона має можливості залучити як аудіалів, так і візуалів, а також - кінестетиків. Саме через це викладачу (англійської мови зокрема) варто користуватися на своїх уроках цими засобами інтерактивного навчання, пояснюючи студентам принципи користування ними.

Висновки. Методична підготовка - це одна 3 найважливіших складових формування професійної компетентності викладача, якій у зв'язку 3 реформуванням освіти і великими суспільними очікуваннями від нових педагогічних кадрів треба приділяти більше уваги як в плані теоретичних досліджень, так і у практичному застосуванні. Інтерактивні методи та засоби навчання - це одні з найефективніших способів роботи з майбутніми педагогічними працівниками, який дозволяє покращити методичну підготовку у таких аспектах, як: теоретична складова; уміння організовувати пізнавальну та позаурочну активність; вміння бути організатором на уроці; вміння вільно володіти іноземною мовою та наочними матеріалами; опанувати складний масив основ педагогіки, психології та дидактики; тренувати навики роботи у педагогічному колективі, а також використовувати під час навчання сучасні засоби інтерактивних технологій. Серед найбільш ефективних методів ми виокремили такі: роботу в парах/трійках; “Карусель”; дискусії, ділові ігри, аналіз ситуацій; 


\section{УДОСКОНАЛЕННЯ МЕТОДИЧНОӤПІДГОТОВКИ МАЙБУТНІХПЕДАГОГІЧНИХ ПРАЦІВНИКІВ ЗАСОБАМИ ІНТЕРАКТИВНОГО НАВЧАННЯНА УРОКАХ АНГЛЙ̆СЫКОӤ МОВИ}

метод акваріуму; “Мозаїка"; рольові методи; "Мікрофон”; “Мозковий штурм” та брейн-ринг.

Перспективу подальших досліджень вбачаємо у можливості детального розгляду окремих методів у контексті методичної підготовки майбутніх педагогічних працівників, а також у проведенні експериментальних перевірок ефективності зазначених методів серед студентів педагогічних вищих учбових закладів.

\section{ЛІТЕРАТУРА}

1. Бабенко Л.В. Використання інтерактивних форм $\mathrm{i}$ методів роботи у навчанні педагогів: методичні рекомендації. Білопілля, 2014. 60 c.

2. Безлюдна В. Зміст підготовки майбугніх учителів іноземних мов у вищих педагогічних навчальних закладах. Проблеми підготовки сучасного вчителя : збірник наукових праць Уманського державного педагогічного університетуімені Павла Тичини. Умань, 2016. Вип. 13. С. 80-87.

3. Бодрова Т. Особливості реалізації системноінтегративного підходу в методичній підготовці майбутніх учителів музики. Естетика і етика педагогічної дії. 2015. Вип. 9. С. 19-32.

4. Зубенко Т. Шляхи удосконалення методичної підготовки вчителів іноземної мови початкових класів Вісник Житомирського педагогічного університету. Педагогічні науки. Житомир, 2003. Вип. 12. С. 212-214.

5. Княжева I.А. Методична підготовка майбутніх викладачів педагогічних дисциплін в умовах магістратури. Наукові записки. Серія: Психологопедагогічні науки (Ніжинський державний університет ім. Миколи Гоголя). Ніжин, 2013. Вип. 1. С. 177-182.

6. Ковирягіна Н. Класифікація інтерактивних методів. Використання інтерактивних технологій в навчально-виховному процесі. Харків, 2010. С. 8-13.

7. Козаченко В. Використання інтерактивних технологій у підготовці майбугніх учителів іноземних мов. Наукові записки Національного педагогічного університету ім. М.П. Драгоманова. Серія: Педагогічні та історичні науки. Київ, 2014. Вип. 117. С. 62-68.

8. Куріч М. Використання інтерактивних технологій на уроках іноземної мови. Нова педагогічна думка. Рівне, 2013. Вип. 2. С. 80-83.

9. Опитування: $67 \%$ українців знають про освітню реформу, підтримують - 37\% : матеріал від 09.11.2017 / / Сайт “Нова Українська Школа”. URL: http://nus.org.ua/ news/opytuvannya-67-ukrayintsiv-znayut-pro-osvitnyureformu-pidtrymuyut-37/ (дата звернення: 02.02.2019).

10. Соснова М. Інтерактивні методи навчання у професійній підготовці молодших медичних спеціалістів. Вісник Національної академії Державної прикордонної служби України. Серія : Педагогіка. Хмельницький, 2016. Вип. 4. URL: http://nbuv.gov.ua/ UJRN/Vnadped 2016414 (дата звернення: 02.02.2019).

\section{REFERENCES}

1. Babenko, L.V. (2014). Vykorystannja interaktyvnyh form $i$ metodiv roboty $u$ navchanni pedagogiv: metodychni rekomendacii [The use of interactive forms and methods of work in the training of teachers: guidelines]. Belopolye, 60 p. [in Ukrainian].

2. Bezljudna, V. (2016). Zmist pidgotovky majbutnih uchyteliv inozemnyh mov u vyshhyh pedagogichnyh navchal'nyh zakladah [Contents of training of future teachers of foreign languages in higher educational institutions]. Problems of training of the modern teacher: the collection of scientific works of Uman state pedagogical University named after Pavel Tychina, Vol. 13, pp. 80-87. [in Ukrainian].

3. Bodrova, T. (2015). Osoblyvosti realizacii' systemnointegratyvnogo pidhodu $\mathrm{v}$ metodychnij pidgotovci majbutnih uchyteliv muzyky [Features of realization of system-integrative approach in methodical preparation of future teachers of music]. Aesthetics and ethics of pedagogical influence, Vol. 9, pp. 19-32. [in Ukrainian].

4.Zubenko, T.(2003). Shljahyudoskonalennja metodychnoi' pidgotovky vchyteliv inozemnoi movy pochatkovyh klasiv [Ways of improvement of methodical preparation of teachers of a foreign language of primary classes]. Bulletin of Zhytomyr pedagogical University. Pedagogical science. Zhytomyr, Vol. 12,pp. 212-214. [inUkrainian].

5. Knjazheva, I.A. (2013). Metodychna pidgotovka majbutnih vykladachiv pedagogichnyh dyscyplin v umovah magistratury [Methodical preparation of future teachers of pedagogical disciplines in the conditions of magistracy]. Scientific notes. Series: Psychological and pedagogical Sciences (Nizhyn state University. Nikolai Gogol). Vol. 1, pp. 177-182. [in Ukrainian].

6. Kovyrjagina, N. (2010). Klasyfikacija interaktyvnyh metodiv [Classification of interactive methods]. Usage of interactive technologies in the educational process. Kharkiv, pp. 8-13. [in Ukrainian].

7. Kozachenko, V. (2014). Vykorystannja interaktyvnyh tehnologij u pidgotovci majbutnih uchyteliv inozemnyh mov [The use of interactive technologies in the training of future teachers of foreign languages]. [in Ukrainian].

8. Kurich, M. (2013). Vykorystannja interaktyvnyh tehnologij na urokah inozemnoi movy [Usage of interactive technologies at foreign language lessons]. New pedagogical thought. Rivne, Vol. 2,pp. 80-83. [in Ukrainian].

9. Opytuvannia: $67 \%$ ukraintsiv znaiut pro osvitniu reformu, pidtrymuiut $-37 \%$ : material vid 09.11.2017 [Poll: $67 \%$ of Ukrainians know about education reform, support 37\%: material from 09.11.2017]. "New Ukrainian School". Available at: http://nus.org.ua/news/opytuvannya-67ukrayintsiv-znayut-pro-osvitnyu-reformu-pidtrymuyut-37/ (Accessed:02 Feb.2019). [in Ukrainian].

10. Sosnova, M. (2016). Interaktyvni metody navchannja u profesijnij pidgotovci molodshyh medychnyh specialistiv [Interactive methods of training in vocational training of junior medical specialists]. Bulletin of the National Academy of the state border service of Ukraine. Series: Pedagogy. Khmelnitsky, Vol. 4. Availableat: http:/nbuv.gov.ua/UJRN/Vnadped 2016_4_14 (date accessed:02.02.2019). [in Ukrainian].

Стаття надійшла до редакції 18.03.2019 